IZA DP No. 4466

Kindergarten Enrollment and the Intergenerational Transmission of Education

Philipp C. Bauer

Regina T. Riphahn

September 2009 


\title{
Kindergarten Enrollment and the Intergenerational Transmission of Education
}

\author{
Philipp C. Bauer \\ economiesuisse \\ Regina T. Riphahn \\ Uniersity of Erlangen-Nuremberg \\ and IZA

\section{Discussion Paper No. 4466 \\ September 2009} \\ IZA \\ P.O. Box 7240 \\ 53072 Bonn \\ Germany \\ Phone: +49-228-3894-0 \\ Fax: +49-228-3894-180 \\ E-mail: iza@iza.org
}

Any opinions expressed here are those of the author(s) and not those of IZA. Research published in this series may include views on policy, but the institute itself takes no institutional policy positions.

The Institute for the Study of Labor (IZA) in Bonn is a local and virtual international research center and a place of communication between science, politics and business. IZA is an independent nonprofit organization supported by Deutsche Post Foundation. The center is associated with the University of Bonn and offers a stimulating research environment through its international network, workshops and conferences, data service, project support, research visits and doctoral program. IZA engages in (i) original and internationally competitive research in all fields of labor economics, (ii) development of policy concepts, and (iii) dissemination of research results and concepts to the interested public.

IZA Discussion Papers often represent preliminary work and are circulated to encourage discussion. Citation of such a paper should account for its provisional character. A revised version may be available directly from the author. 
IZA Discussion Paper No. 4466

September 2009

\section{ABSTRACT \\ Kindergarten Enrollment and the Intergenerational Transmission of Education}

We use Swiss data to test whether intergenerational educational mobility is affected by the age at which children enroll in kindergarten. Taking advantage of heterogeneity across cantons we find that early kindergarten enrollment significantly increases educational mobility.

JEL Classification: $\quad 12,121, \mathrm{~J} 24, \mathrm{D} 30$

Keywords: Kindergarten, pre-school enrollment, educational mobility, intergenerational transmission of education

Corresponding author:

Regina T. Riphahn

University of Erlangen-Nuremberg

Lange Gasse 20

90403 Nürnberg

Germany

E-mail: regina.riphahn@wiso.uni-erlangen.de 


\section{Introduction}

High intergenerational transmission of educational attainment within families is one of the major roadblocks on the way to equal opportunities in the labor market and beyond. A large literature has attempted to separate genetic and behavioral determinants of intergenerational education transmission (e.g. Björklund et al. 2006). In addition, institutional factors have been investigated as potential determinants of educational mobility. Past studies of such institutional or 'school design' issues focused, e.g., on school tracking and its timing or on age at school entry. The former confirm that early tracking reduces educational mobility, presumably because child ability measures at early age are noisy and tracking decisions follow parental preferences more than child characteristics (Hanushek and Wößmann 2006). Studies on the relevance of school entry age argue that early schooling may equalize educational endowment differences (Currie 2001).

We extend the literature on school design as a determinant of intergenerational mobility and investigate the causal effect of kindergarten enrollment age on educational mobility, which has not been studied so far. Kindergarten enrollment age and time spent in pre-school have been evaluated with respect to their effect on school and labor market attainment (e.g. Elder and Lubotsky 2009). Deming and Dynarski (2008) suggest that postponing kindergarten and school entry increases inequality because unequal backgrounds predominate longer in a child's life. Since particularly the better-educated parents postpone the school entry of their children, the authors argue that the disadvantage of other children is enhanced. Two methodological problems in identifying causal age at entry effects are that (i) age at entry is endogenously determined at the individual level and (ii) it is difficult to empirically separate the effects of age from those of age at entry.

We solve the first problem by taking advantage of exogenous variation in age at kindergarten entry across 26 Swiss cantons. We address the second problem by investigating 
educational outcomes that are not age-specific: given the Swiss secondary schooling system with ability-based tracks, we evaluate the correlation between parental education and the child's probability of attending the highest and most academically-oriented track. We compare this correlation across exogenously set kindergarten entry age regimes. This identifies the effect of kindergarten entry age on intergenerational educational mobility if the standard assumption of the difference-in-differences approach holds, i.e., if we were to observe the same or similar patterns of intergenerational mobility across cantons in the absence of heterogeneous kindergarten regulations. Since the overall education system is generally homogenous across the 26 Swiss cantons this standard assumption appears to be plausible and we can identify causal effects of kindergarten regulations by comparing educational mobility across cantons.

\section{Data and Empirical Approach}

Our data are taken from the 2000 census which provides information on the entire Swiss population. In order to evaluate the effect of parental education on child educational outcomes we code the type of secondary school a youth attends at age 17 (high - middle low) as well as parents' highest educational degree completed. ${ }^{1}$ We focus on the group of 17 years-olds (the birth cohort of 1983) first, because at the age of 17 track choice is completed and second, because this group is most likely to still live in the parental household: in the census data we can only connect parent and child observations if both reside in the same household (see Bauer and Riphahn 2007 for further detail). Our sample consists of 62,535 observations.

The Swiss Federal Statistical Office provided us with cantonal data on (i) the number

${ }^{1}$ Parental education is coded using as possible outcomes: high, middle, and low educational degrees, education information missing, or parent missing. 
of 4/5/6-years-olds in kindergarten in 1987/1988/1989 and their respective population shares, (ii) the average age of children in kindergarten between 1987 and 1989. These are the years when the birth cohort of 1983 was to attend kindergarten. Table 1 describes the heterogeneity in kindergarten utilization across Swiss federal cantons: the average age of kindergarten children is 5.4 years and varies between 4.0 and 6.0. We observe some cantons with about 80 percent of all 4-years-olds in kindergarten and others with no 4-years-olds, some cantons which enroll 96 percent of all 6-years-olds and others with less than ten percent of all 5- and 6-years-olds in kindergarten.

At a descriptive level Table 2 presents the correlation patterns between cantonal average age at kindergarten enrollment and educational mobility. We see (row 1) that the probability for a 17-years-old to attend the highest educational track indeed varies by parental educational background, reaching 11.5 percent if parents have low education (column 1) and 63.3 percent if parents have high education (column 2). The values differ by 51.8 percentage points (column 3) and the latter is higher by a factor 5.5 (column 4). The next rows indicate that the relevance of parental educational background varies significantly depending on the cantonal kindergarten regime: rows 2 and 3 consider only observations in cantons where average kindergarten age is one standard deviation above or below the mean, rows 4 and 5 split the sample in the top and bottom half of all cantons. We see in columns 3 and 4 that the absolute and relative differences in educational mobility vary between the considered pairs: the relative difference factor increases to 10.98 in regions with a high average age in kindergarten (row 3) and to 8.24 in cantons with late kindergarten enrollment (row 5). The pvalues indicate that educational mobility, as described in column 4, is significantly higher if children enter kindergarten early.

In order to test whether this evidence holds up to controls for various composition effects at the household and regional level we estimate multinomial logit regression models. 
The dependent variable describes the educational track attended by the individual child (Y). We control for indicators of parental educational background (PE), household level, regional, and individual characteristics (X), as well as for an indicator of the kindergarten provision (KG) in the canton where the 17 -years-old lives in $2000 .^{2}$ To the extent that families moved across cantonal boundaries after kindergarten age our estimation suffers from measurement error. Finally, we add interaction terms of parental education and kindergarten indicators (PE $\cong \mathrm{KG})$ :

$\mathrm{Y}=\mathrm{a}+\mathrm{b} \mathrm{PE}+\mathrm{c}_{0} \mathrm{X}+\mathrm{c}_{1} \mathrm{KG}+\mathrm{d}(\mathrm{PE} \cong \mathrm{KG})+$,

$\mathrm{MY} / \mathrm{MPE}=\mathrm{b}+\mathrm{d} \mathrm{KG}$

A jointly significant coefficient vector "d" suggests that the impact of parental education varies depending on the level of cantonal kindergarten provision and that educational mobility is on average modified by kindergarten enrollment.

We evaluate the kindergarten effect and its magnitude using predicted probabilities of high (i.e. college-bound) secondary schooling for children of parents with high and low education in scenarios of early and late kindergarten enrollment. The impact of kindergarten enrollment is thus compared in a difference-in-differences type approach.

\section{Results}

We do not present the coefficient estimates of the multinomial logit model to save space (they are available upon request). The vector of interaction terms generated jointly highly significant coefficient estimates. A Hausman test rejected the hypothesis of correlation

${ }^{2}$ The empirical model controls for 8 indicators of paternal and maternal education, 20 indicators of paternal and maternal occupational position, age of father and age of mother, 4 indicators of religion, 3 indicators of the number of siblings, 6 region indicators, population density and youth unemployment in the area of residence, sex of the child, an indicator of the kindergarten regime (average age or share of 4- or 5-years-olds), and 8 interaction terms of 
in unobserved heterogeneities across outcomes. Table 3 presents the predicted probabilities of attending the highest secondary school track conditional on parental education and on the cantonal kindergarten regime. Panel A presents the results when we use the average observed age of kindergarten children as an indicator for the kindergarten regime, Panels B and C show the results when we apply the shares of 4- and 5-years-olds in kindergarten, respectively. ${ }^{3}$ The results are clear and robust across all three panels: the earlier children attend kindergarten (and the higher the share of 4- and 5 years olds in kindergarten) the lower is the impact of parental education on child educational attainment. The p-values in columns 11, 12, 14 and 15 indicate that relative intergenerational mobility is significantly higher (at least at the 10 percent level) when children enroll in kindergarten early. While the same effect also obtains for absolute differences in the conditional probability of attaining high levels of schooling, the absolute differences are not always statistically significant.

\section{Conclusion}

This study tests whether the extent of intergenerational correlation in educational outcomes varies depending on the kindergarten regime in place. We find evidence for a beneficial effect of early enrollment in kindergarten. While the empirical evidence is new to the literature the mechanism is similar to that observed for the age of school entry: the earlier children participate in kindergarten activities the less important is parental background. Therefore child endowment differences, which are connected to parental education, are balanced more successfully and the impact of parental background on educational attainment is reduced by early rather than late kindergarten enrollment.

the kindergarten regime and parental education plus a constant.

${ }^{3}$ Since some cantons require 6-years-olds to attend school the share of 6-years-olds in kindergarten is not used as an indicator. 


\section{References}

Bauer, Philipp and Regina T. Riphahn, 2007, Heterogeneity in the intergenerational transmission of educational attainment: evidence from Switzerland on natives and second generation immigrants, Journal of Population Economics 20(1), 121-148.

Björklund, Anders, Mikael Lindahl, and Erik Plug, 2006, The Origins of Intergenerational Associations: Lessons from Swedish Adoption Data, Quarterly Journal of Economics 121(3), 999-1028.

Currie, Janet, 2001, Early Childhood Education Programs, Journal of Economic Perspectives 15(2), 213-238.

Deming, David and Susan Dynarski, 2008, The Lengthening of Childhood, Journal of Economic Perspectives 22(3), 71-92.

Elder, Todd E. and Darren H. Lubotsky, 2009, Kindergarten Entrance Age and Children's Achievement. Impacts of State Policies, Family Background, and Peers, Journal of Human Resources 44(3), 641-683.

Hanushek, Eric A. and Ludger Wößmann, 2006, Does Educational Tracking Affect Performance and Inequality? Differences-in-Differences Evidence Across Countries, Economic Journal 116(510), C63-C76. 
Table 1 Cantonal kindergarten characteristics

\begin{tabular}{lcrrr}
\hline Variable & Mean & Std.Dev. & Min & Max \\
\hline & & & & \\
Share of 4-years-olds in Kindergarten & 0.152 & 0.228 & 0.000 & 0.825 \\
Share of 5-years-olds in Kindergarten & 0.601 & 0.261 & 0.037 & 0.910 \\
Share of 6-years-olds in Kindergarten & 0.683 & 0.231 & 0.090 & 0.957 \\
Average Age in Kindergarten & 5.407 & 0.474 & 4.018 & 6.027 \\
\hline
\end{tabular}

Source: Information on kindergarten regimes at the level of $(\mathrm{N}=26)$ cantons 1987-1989 is provided by the Swiss Statistical Office, Section School and Vocational Education.

Table 2 Observed probability of child high secondary education by paternal education and cantonal age at school entry

\begin{tabular}{|c|c|c|c|c|c|c|}
\hline & $\begin{array}{c}\mathrm{P} \text { (high | low) } \\
1\end{array}$ & $\begin{array}{l}\text { P (high | high) } \\
2\end{array}$ & $\begin{array}{l}\text { Absolute Diff. } \\
3\end{array}$ & $\mathrm{p}$ & $\begin{array}{c}\text { Relative Diff. } \\
4\end{array}$ & $p$ \\
\hline 1 All & $0.115(0.004)$ & $0.633(0.006)$ & $0.518(0.007)$ & & 5.524 & \\
\hline 2 Average Age $<1$ Std.Dev. & $0.290(0.013)$ & $0.770(0.011)$ & $0.481(0.017)$ & 0.441 & $2.659(1.202)$ & 0.000 \\
\hline 3 Average Age $>1$ Std.Dev. & $0.063(0.011)$ & $0.691(0.037)$ & $0.628(0.039)$ & & $10.983(0.287)$ & \\
\hline 4 Early Age Cantons & $0.176(0.007)$ & $0.681(0.008)$ & $0.505(0.010)$ & 0.502 & $3.873(0.876)$ & 0.000 \\
\hline 5 Late Age Cantons & $0.069(0.004)$ & $0.570(0.009)$ & $0.501(0.010)$ & & $8.237(0.415)$ & \\
\hline
\end{tabular}

Note: P (high | low) describes the probability that children of fathers with low education pursue the high secondary track, $\mathrm{P}$ (high | high) provides the same probability for children of highly educated fathers. Row 1 column 1 uses 7,680 observations, row 1 column 2 is based on 6,651 observations. The entries in rows 2-4 are based on subsamples thereof. Standard errors are in parentheses. The p-values apply to one sided tests of the null hypotheses that the differences of the absolute and relative differences in columns 3 and 4 are larger in early than in the late kindergarten enrollment regimes. 
Table 3 Predicted probability of child high secondary education by parental education and cantonal enrolment regime

\begin{tabular}{|c|c|c|c|c|c|c|c|c|c|c|c|c|c|c|c|}
\hline & \multicolumn{3}{|c|}{ Predicted Probability } & \multicolumn{6}{|c|}{ Absolute Differences } & \multicolumn{6}{|c|}{ Relative Differences } \\
\hline & 1 & 2 & 3 & 4 & 5 & 6 & 7 & 8 & 9 & 10 & 11 & 12 & 13 & 14 & 15 \\
\hline & $\begin{array}{l}\text { P (high } \\
\text { | low) }\end{array}$ & $\begin{array}{l}P \text { (high } \\
\text { | mid) }\end{array}$ & $\begin{array}{l}\mathrm{P} \text { (high } \\
\text { | high) }\end{array}$ & $=3-1$ & $\begin{array}{c}\text { p-value } \\
\text { of diff. } \\
a-b \\
\text { and b- }\end{array}$ & $\begin{array}{l}\text { p-value } \\
\text { of diff. } \\
\text { a-c }\end{array}$ & $=3-2$ & $\begin{array}{c}p \text {-value } \\
\text { of diff. } \\
a-b \\
\text { and } b-\end{array}$ & $\begin{array}{c}\text { p-value } \\
\text { of diff. } \\
\text { a-c }\end{array}$ & $=3 / 1$ & $\begin{array}{c}\text { p-value } \\
\text { of diff. } \\
a-b \\
\text { and b- }\end{array}$ & $\begin{array}{c}\text { p-value } \\
\text { of diff. } \\
\text { a-c }\end{array}$ & $=3 / 2$ & $\begin{array}{c}\text { p-value } \\
\text { of diff. } \\
a-b \\
\text { and b- }\end{array}$ & $\begin{array}{c}\text { p-value } \\
\text { of diff. } \\
\text { a-c }\end{array}$ \\
\hline \multicolumn{16}{|l|}{ A: Effect of Average Kindergarten Age } \\
\hline a Average age at mean - 1 Std.Dev. & $\begin{array}{c}0.118 \\
(0.082)\end{array}$ & $\begin{array}{l}0.261 \\
(0.14)\end{array}$ & $\begin{array}{c}0.629 \\
(0.169)\end{array}$ & $\begin{array}{c}0.512 \\
(0.108)\end{array}$ & 0.219 & & $\begin{array}{c}0.368 \\
(0.066)\end{array}$ & 0.063 & & $\begin{array}{c}5.354 \\
(2.736)\end{array}$ & 0.047 & & $\begin{array}{c}2.412 \\
(0.842)\end{array}$ & 0.041 & \\
\hline b Average age at mean & $\begin{array}{l}0.081 \\
(0.06)\end{array}$ & $\begin{array}{c}0.212 \\
(0.123)\end{array}$ & $\begin{array}{l}0.614 \\
(0.17)\end{array}$ & $\begin{array}{c}0.533 \\
(0.123)\end{array}$ & 0.349 & 0.271 & $\begin{array}{c}0.402 \\
(0.076)\end{array}$ & 0.125 & 0.090 & $\begin{array}{c}7.561 \\
(3.999)\end{array}$ & 0.045 & 0.046 & $\begin{array}{c}2.898 \\
(1.103)\end{array}$ & 0.041 & 0.041 \\
\hline c Average age at mean +1 Std.Dev. & $\begin{array}{r}0.055 \\
(0.043) \\
\end{array}$ & $\begin{array}{r}0.169 \\
(0.107) \\
\end{array}$ & $\begin{array}{r}0.597 \\
(0.171) \\
\end{array}$ & \begin{tabular}{|c|}
0.542 \\
$(0.137)$ \\
\end{tabular} & & & $\begin{array}{c}0.427 \\
(0.088) \\
\end{array}$ & & & $\begin{array}{c}10.836 \\
(5.85) \\
\end{array}$ & & & $\begin{array}{c}3.524 \\
(1.439) \\
\end{array}$ & & \\
\hline \multicolumn{16}{|l|}{ B: Effect of Share of 4 Years Olds } \\
\hline a Average - 1 Std.Dev. & $\begin{array}{c}0.071 \\
(0.056)\end{array}$ & $\begin{array}{c}0.198 \\
(0.123)\end{array}$ & $\begin{array}{c}0.612 \\
(0.171)\end{array}$ & $\begin{array}{c}0.541 \\
(0.128)\end{array}$ & 0.134 & & $\begin{array}{c}0.414 \\
(0.079)\end{array}$ & 0.026 & & $\begin{array}{c}8.667 \\
(4.852)\end{array}$ & 0.074 & & $\begin{array}{c}3.090 \\
(1.255)\end{array}$ & 0.076 & \\
\hline b Average share of 4 years olds & $\begin{array}{c}0.084 \\
(0.066)\end{array}$ & $\begin{array}{l}0.216 \\
(0.13)\end{array}$ & $\begin{array}{c}0.612 \\
(0.172)\end{array}$ & $\begin{array}{c}0.528 \\
(0.122)\end{array}$ & 0.092 & 0.100 & $\begin{array}{c}0.397 \\
(0.075)\end{array}$ & 0.019 & 0.022 & $\begin{array}{c}7.265 \\
(3.936)\end{array}$ & 0.069 & 0.071 & $\begin{array}{c}2.837 \\
(1.094)\end{array}$ & 0.071 & 0.073 \\
\hline c Average +1 Std.Dev. & $\begin{array}{r}0.109 \\
(0.081) \\
\end{array}$ & $\begin{array}{l}0.244 \\
(0.14) \\
\end{array}$ & $\begin{array}{c}0.612 \\
(0.173) \\
\end{array}$ & $\begin{array}{c}0.503 \\
(0.112) \\
\end{array}$ & & & $\begin{array}{l}0.367 \\
(0.07) \\
\end{array}$ & & & $\begin{array}{c}5.612 \\
(2.885) \\
\end{array}$ & & & $\begin{array}{r}2.503 \\
(0.891) \\
\end{array}$ & & \\
\hline \multicolumn{16}{|l|}{ C: Effect of Share of 5 Years Olds } \\
\hline a Average - 1 Std.Dev. & $\begin{array}{c}0.064 \\
(0.057)\end{array}$ & $\begin{array}{c}0.188 \\
(0.128)\end{array}$ & $\begin{array}{c}0.584 \\
(0.182)\end{array}$ & $\begin{array}{c}0.520 \\
(0.139)\end{array}$ & 0.434 & & $\begin{array}{c}0.396 \\
(0.087)\end{array}$ & 0.333 & & $\begin{array}{c}9.092 \\
(5.331)\end{array}$ & 0.080 & & $\begin{array}{c}3.105 \\
(1.284)\end{array}$ & 0.077 & \\
\hline b Average share of 5 years olds & $\begin{array}{c}0.086 \\
(0.073)\end{array}$ & $\begin{array}{c}0.214 \\
(0.138)\end{array}$ & $\begin{array}{c}0.602 \\
(0.181)\end{array}$ & $\begin{array}{c}0.516 \\
(0.127)\end{array}$ & 0.338 & 0.383 & $\begin{array}{l}0.388 \\
(0.08)\end{array}$ & 0.281 & 0.306 & $\begin{array}{c}6.963 \\
(3.964)\end{array}$ & 0.073 & 0.076 & $\begin{array}{c}2.811 \\
(1.128)\end{array}$ & 0.069 & 0.074 \\
\hline c Average + 1 Std.Dev. & $\begin{array}{c}0.115 \\
(0.091) \\
\end{array}$ & $\begin{array}{c}0.243 \\
(0.148) \\
\end{array}$ & $\begin{array}{l}0.620 \\
(0.18)\end{array}$ & $\begin{array}{c}0.505 \\
(0.114) \\
\end{array}$ & & & $\begin{array}{c}0.378 \\
(0.075)\end{array}$ & & & $\begin{array}{c}5.392 \\
(2.996) \\
\end{array}$ & & & $\begin{array}{c}2.555 \\
(0.999) \\
\end{array}$ & & \\
\hline
\end{tabular}

Note: P (high | low) describes the probability that children of fathers with low education pursue the high secondary track, the other probabilities similarly condition on fathers' education. In parentheses are bootstrapped standard errors, the p-values (in columns 5, 6, 8, 9, 11, 12, 14, 15) apply to one-sided tests of the null hypotheses that the differences (presented in columns 4, 7, 10 and 13) are larger in the early than in the late kindergarten enrollment regimes. Bold faced font indicates p-values at 10 percent or below.

Source: Own calculations based on Census 2000 and on a survey of cantonal education departments. 